\title{
STUDI MENGENAI TRANSFORMASI EKONOMI BERBASIS PARIWISATA DI PROVINSI KALIMANTAN SELATAN
}

\section{STUDY ON TOURISM-BASED ECONOMIC TRANSFORMATION IN SOUTH KALIMANTAN PROVINCE}

\author{
Fitri Handayani \\ Badan Pusat Statistik Provinsi Kalimantan Selatan \\ Jl. Soekarno Hatta/Trikora No. 7 Banjarbaru \\ Email: fitri.fhandayani@gmail.com \\ Naskah diterima : 28 November 2017, Direvisi : 26Januari 2018, \\ Disetujui : 30Januari 2018
}

\begin{abstract}
According to the unstable economy if theeconomy is depend on the mining sector, it is necessary for the government of South Kalimantan Province considering to encourage the economic activities of other sectors. Tourism is one sector that can be considered. The purpose of this paper is to know the impact of the tourism sector on other sectors in South Kalimantan and to find out the province's readiness to make tourism as a leading sector. The research method used is the analysis of Input-Output table. Based on the results of the analysis,the tourism sector has a spread of power index of 0.937 which means its influence on all sectors of the economy closely but not too strong. Meanwhile, the sensitivity index is 1.443 (above average for all sectors). Based on spread of power and sensitivity index, the tourism sector is quite ready to become a key or leading sector in South Kalimantan. From the result of output and income impact analysis, tourism sector which become priority is transportation, trade, and restaurant sub sector.
\end{abstract}

Keywords: tourism, Input-Output analysis, economy impact.

\begin{abstract}
Abstrak
Berkaitan dengan kurang stabilnya suatu ekonomi jika bergantung dengan sektor pertambangan, perlu adanya pertimbangan pemerintah Provinsi Kalimantan Selatan untuk mendorong aktivitas ekonomi sektor lain. Pariwisata merupakan salah satu sektor yang dapat menjadi pertimbangan.Tujuan dari paper ini adalah untuk mengetahui dampak sektor pariwisata terhadap sektor lainnya di Kalimantan Selatan dan untuk mengetahui kesiapan provinsi tersebut untuk menjadikan pariwisata sebagai ekonomi unggulan. Metode penelitian yang digunakan adalah analisis tabel Input-Output. Berdasarkan hasil analisis tersebut, sektor pariwisata memiliki nilai indeks daya penyebaran 0,937 yang
\end{abstract}


berarti pengaruhnya terhadap seluruh sektor ekonomi erat namun tidak terlalu kuat. Sedangkan, indeks derajat kepekaan 1,443 (di atas rata-rata seluruh sektor).Berdasarkan indeks daya penyebaran dan derajat kepekaan, sektor pariwisata cukup siap untuk menjadi sektor kunci atau unggulan di Kalimantan Selatan. Dari hasil analisis dampak output dan pendapatan, sektor pariwisata yang menjadi prioritas adalah subsektor angkutan, perdagangan, dan restoran/rumah makan.

Kata kunci: pariwisata, analisis Input-Output, dampak ekonomi.

\section{A. PENDAHULUAN}

Wilayah yang kaya akan sumber daya alam merupakan suatu anugerah karena kegiatan ekonominya dengan mudah dapat diperoleh dari sumber tersebut. Seperti halnya Provinsi Kalimantan Selatan dimana kontribusi sektor yang berbasis sumber daya alam mendominasi sekitar 35 persen perekonomian wilayah tersebut pada tahun 2016. Sektor itu terdiri dari kegiatan pertanian dan pertambangan. Hal ini membuat adanya ketergantungan Kalimantan Selatan terhadap kondisi alam yang ada.

Dari sisi andil terhadap ekonomi, aktivitas ekonomi pertambangan masih lebih tinggi dibanding pertanian. Jika dilihat dari perbandingannya terhadap Produk Domestik Regional Bruto (PDRB), pertambangan memiliki peran sekitar 20 persen sejak tahun 2010 hingga 2016. Bahkan pada tahun 2011, kontribusinya mencapai 30 persen. Sedangkan pertanian, kontribusinya hanya berkisar 15 persen terhadap total ekonomi Kalimantan Selatan. Sehingga dapat dikatakan bahwa ekonomi Kalimantan Selatan berkaitan erat dengan kondisi produktivitas pertambangannya.

Dengan melihat dari sisi positif dominasi pertambangan, ada aset alam yang dapat dimanfaatkan untuk peningkatan ekonomi wilayah. Namun, jika dikaji lebih dalam terkait dampak negatifnya, pertambangan terutama batubara merupakan sumber daya yang tidak dapat diperbaharui. Sehingga, lama kelamaan produksi batubara itu sendiri akan habis. Jika sudah tidak ada lagi produksinya, aktivitas ekonomi yang berkaitan dengan batubara tersebut akan terhenti. Selain itu, harga batubara saat ini juga semakin tidak menentu. Ketika harga batubara menurun, investor akan mengurangi minatnya untuk mendanai kegiatan tersebut. Sektor perbankan pun akan mengurangi bahkan menghentikan pendanaannya terkait pertambangan karena melemahnya produksi pertambangan.

Ketidakstabilan kondisi pertambangan batubara akan sangat berdampak pada kondisi ekonomi Kalimantan Selatan. Hal ini pun sudah terlihat pada beberapa tahun terakhir sejak mulai tidak stabilnya harga batubara. Dari grafik di bawah terlihat bahwa pertumbuhan pertambangan batubara diiringi oleh pergerakan pertumbuhan total ekonomi Kalimantan Selatan, dimana puncak pertumbuhan ekonomi sekaligus pertambangan batubara ada pada tahun 2011. Namun sejak tahun 2012, kondisi pertambangan batubara terus melambat menyebabkan pertumbuhan total ekonomi juga mengalami perlambatan. Meskipun di tahun 2016 kondisi harga batubara mulai membaik yang diikuti perbaikan pertumbuhan ekonomi Kalimantan Selatan, namun ini tidak menjadi jaminan bahwa perbaikan harga batubara akan terus berlanjut. 


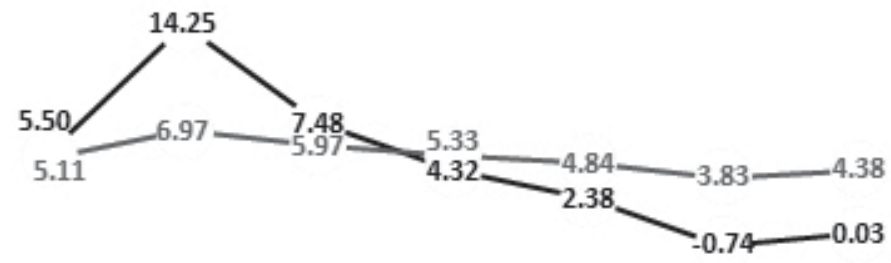

$\begin{array}{cccccc}2010 & 2011 & 2012 & 2013 & 2014 & 2015\end{array} 2016$

Sumber: BPS Provinsi Kalimantan Selatan, 2017

Gambar 1.

Pertumbuhan Kategori Pertambangan Batubara dan Lignit dan Pertumbuhan Ekonomi Provinsi

Kalimantan Selatan Tahun 2010 - 2016

Selain itu, saat ini ekonomi yang memperhatikan lingkungan menjadi fokus utama di sebagian besar negara di dunia. Peningkatan kesadaran akan dampak negatif aktivitas ekonomi terhadap lingkungan dapat menjadi sinyalharus dikuranginya kegiatan yang berkaitan dengan eksploitasi alam, seperti halnya pertambangan batubara. Deplesi menjadi salah satu indikator semakin tergerusnya lingkungan sumber daya alam di suatu wilayah. Sehingga diharapkan aktivitas ekonomi yang berkaitan dengan pengeksploitasian alam semakin dikurangi. Hal ini akan membuat produksi batubara juga akan semakin dikurangi dan digantikan dengan produk yang lebih ramah lingkungan.

Berkaitan dengan kurang stabilnya suatu ekonomi jika bergantung dengan sektor pertambangan, perlu adanya pertimbangan pemerintah Provinsi Kalimantan Selatan untuk meningkatkan dan mendorong aktivitas ekonomi sektor lain. Sehingga jika saat pertambangan batubara mulai menghilang, perekonomian provinsi tersebut tidak ikut menurun maupun melambat.Selain itu, ketidakstabilan sektor pertambangan ini juga akan sangat berpengaruh pada kondisi tenaga kerja yang bergantung pada sektor tersebut. Penurunan aktivitas pada sektor tersebut berdampak pada tingkat pengangguran yang akan bergerak naik.

Pariwisata merupakan salah satu sektor yang dapat menjadi pertimbangan. Menurut Guan Zhongmei dan Wang Juan (2012), ekonomi yang berbasis pada pariwisata akan memiliki dampak multiplier terhadap sektor lainnya. Selain itu, pariwisata juga dianggap sebagai salah satu industri hijau dimana sektor ini memperkenalkan suatu jenis perkembangan perlindungan antara lingkungan dan manusia.Dengan dijadikannya pariwisata sebagai fundamental suatu wilayah, hal ini dapat menciptakan lingkungan yang indah sehingga dapat meningkatkan popularitas wilayah tersebut serta dapat meningkatkan daya saing dibanding wilayah lain. Kemudian jika dilihat dari segi tenaga kerja, menurut estimasi World Tourism Organization, satu tenaga kerja di sektor pertambangan berarti membuka kesempatan untuk lima tenaga kerja di sektor itu sendiri dan sektor lainnya (Guan Zhongmei dan Wang Juan, 2012).

Menurut Bansal \& Eiselt (dalam Manhas dkk, 2016), dalam beberapa tahun terakhir, pariwisata merupakan salah satu industri yang paling penting dan konsisten di seluruh dunia dan saat ini dianggap sebagai salah satu industri jasa yang utama. Kebutuhan manusia akan relaksasi dari berbagai pekerjaannya pun memang semakin meningkat. Selain itu, dengan semakin intensnya berbagi di media sosial, kebutuhan pengalaman pariwisata dan bersantai menjadi salah satu yang sering dibagikan melalui jaringan tersebut. Hal ini membuat permintaan akan industri pariwisata yang lebih baik menjadi semakin meningkat. 
Pemerintah Indonesia sendiri pun sudah mulai memfokuskan ekonomi pada industri pariwisata, yang ditargetkan pada tahun 2019 jumlah wisatawan nasional mencapai 275 juta orang dan jumlah wisatawan mancanegara mencapai 20 juta orang. Pemerintah Provinsi Kalimantan Selatan menargetkan untuk berkontribusi pada jumlah wisatawan, yaitu satu juta orang untuk wisatawan nasional dan tujuh ribu wisatawan mancanegara. Namun, jika dilihat berdasarkan data Badan Pusat Statistik, jumlah wisatawan yang datang menurut klasifikasi akomodasi dan jenis wisatawan tahun 2016, wisatawan nusantara baru mencapai 1.423 .553 orang dan wisatawan mancanegara sebesar 6.319 orangsehingga perlu upaya pemerintah untuk terus meningkatkan industri pariwisata di Kalimantan Selatan.

Berdasarkan pentingnya Kalimantan Selatan untuk bertransformasi dalam hal ekonomi dari sektor pertambangan ke sektor pariwisata, maka paper ini bertujuan untuk mengetahui dampak sektor pariwisata terhadap sektor lainnya di Kalimantan Selatan. Selain itu untuk mencapai target pemerintah, perlu dilakukan kajian mengenai kesiapan Kalimantan Selatan untuk menjadikan pariwisata sebagai ekonomi unggulan.

\section{B. METODE PENELITIAN}

Penelitian ini menggunakan jenis data sekunder dari tabel input output Provinsi Kalimantan Selatan tahun 2010: Transaksi Domestik Atas Dasar Harga Produsen dengan klasifikasi 50 sektor yang bersumber dari Badan Pusat Statistik Provinsi Kalimantan Selatan.Dari 50 sektor tersebut, dilakukan agregasi menjadi 11 sektor, dimana di dalamnya termasuk sektor pariwisata.Sektor pariwisata tersebut dirincikan pula ke dalam 6 subsektor, yaitu perdagangan, jasa akomodasi, restoran/ rumah makan, transportasi; jasa penunjang angkutan dan pergudangan, jasa hiburan dan rekreasi.

Metode analisis yang digunakan adalah metode analisis Input-Output. Metode Input-Output adalah suatu analisis tentang perekonomian suatu wilayah yang bertujuan untuk melihat keterkaitan antar sektor ekonomi di suatu wilayah secara keseluruhan.Dalam beberapa literatur yang membahas tentang Tabel I-O, asumsi yang mendasari adalah sebagai berikut (Badan Pusat Statistik, 2010):

1. Asumsi keseragaman/homogenitas yang mensyaratkan bahwa tiap sektor memproduksi suatu output tunggal dengan struktur input tunggal dan bahwa tidak ada barang serupa atau substitusi yang dihasilkan oleh sektor lain.

2. Asumsi kesebandingan/proportionalitasyang mensyaratkan bahwa dalam proses produksi, hubungan antara input dan output merupakan fungsi lurut (linier), yaitu naik atau turunnya setiap jenis input yang diserap oleh sektor tertentu sebanding dengan kenaikan atau penurunan output sektor tersebut.

3. Asumsi penjumlahan/additivitas yang menyebutkan bahwa efek total pelaksanaan produksi di berbagai sektor dihasilkan dari masing-masing sektor secara terpisah, dan merupakan penjumlahan dari efek masing-masing kegiatan. Ini berarti bahwa semua pengaruh dari luar sistem input-output diabaikan.

Kegunaan tabel Input-Output adalah untuk meneliti tingkat saling keterkaitan diantara berbagai sektor dalam suatu ekonomi. Selain itu,tabel Input-Output juga dapat melihat gambaran mengenai kontribusi suatu sektor ekonomi terhadap ekonomi secara keseluruhan atau potensi pertumbuhan suatu sektor ekonomi tertentu.

Analisis dibedakan menjadi analisis keterkaitan dan analisis pengganda.Analisis keterkaitan terdiri dari keterkaitan ke belakang (backward linkage) dan keterkaitan ke depan (forward linkage). Keterkaitan ke belakang adalah menghitung peningkatanoutput sektor tertentu yang akan mendorong 
peningkatan output sektor-sektor lainnya. Keterkaitan ke belakang ini diperoleh dari penjumlahan seluruh baris suatu matriks Leontif Inverse Matriks((I-Ad $\left.)^{-1}\right)$ dalam suatu kolom.Keterkaitan ke depan adalah menghitungtotal output yang tercipta akibatmeningkatnya output suatu sektor industrimelalui mekanisme distribusi output dalamperekonomian.Keterkaitan ke depanini diperoleh dari penjumlahan seluruh kolom suatu matriks Leontif Inverse Matriks ((I-Ad $\left.)^{-1}\right)$ dalam suatu baris.

Dari analisis keterkaitan ini dapat dibentuk juga dalam suatu indeks dengan membuat rata-rata terhadap seluruh sektor, yaitu indeks daya penyebaran dan indeks derajat kepekaan. Jika indeks daya penyebaran $\left(\alpha_{j}\right)$ lebih dari 1 , maka pengaruh permintaan produk sektor $\mathrm{j}$ terhadap pertumbuhan sektor-sektor lainnya tinggi. Sebaliknya jika $\alpha_{j}<1$, maka pengaruh permintaan produk sektor j terhadap pertumbuhan sektor-sektor lainnya rendah. Jika indeks derajat kepekaan $\left(\beta_{\mathrm{i}}\right)$ lebih dari 1 , maka permintaan produk sektor lain sangat berpengaruh pada pertumbuhan sektor $i$, begitu pula sebaliknya.

Analisis dampakyang dihitung dalam paper ini adalah analisis dampak output dan Nilai Tambah Bruto (NTB). Analisis dampak output digunakan untuk menghitung porsi output yang terbentuk sebagai dampak dari masing-masing komponen permintaan akhir dan memperkirakan output terbentuk akibat dampak permintaan akhir yang diproyeksikan. Output dalam model input output dihitung dengan rumus : $\mathrm{X}_{\mathrm{FD}}=\left(\mathrm{I}-\mathrm{A}^{\mathrm{d}}\right)^{-1} \mathrm{~F}^{\mathrm{d}}$. Rumusan ini mencerminkan bahwa pembentukan output (X) dipengaruhi oleh permintaan akhir $\left(\mathrm{F}^{\mathrm{d}}\right)$.Analisis dampak NTBdiperoleh dari rumus : $\mathrm{V}=\mathrm{vX}$, dimana $v$ adalah matriks NTB; adalah matriks diagonal koefisien NTB; $X=\left(I-A^{d}\right)^{-1} F^{d}$.

\section{KERANGKA TEORI}

\section{Transformasi Ekonomi}

Perubahan struktural dapat didefinisikan sebagai perubahan kepentingan relatif sektor ekonomi.Proses perubahan struktural yang terkait pembangunan ekonomi secara bersama-sama disebut sebagai transformasi ekonomi(Syrquin 1988, dalam Breisinger\& Xinshen 2008). Sebagai bagian dari pembangunan, transformasi ekonomi dapat didefinisikan sebagai proses dinamis dimana ekonomi, sosial, dan institusi suatu negara dimodernisasi dan bergerak ke level yang lebih maju.

Pembangunan adalah tentang mengubah struktur produktif ekonomi dan mengumpulkan kemampuan yang diperlukan untuk melakukan proses tersebut(Kuznets 1966, dalam ADB 2013).Menurut literatur tersebut, pembangunan adalah proses dimana munculnya aktivitas baru, menghilangnya aktivitas lama, sumber daya beralih dari kegiatan yang kurang produktif menjadi lebih produktif, serta bobot sektor ekonomi dan pola interaksi berubah secara regular.Pembangunan berbeda dari pertumbuhan agregat, yang dapat terjadi tanpa transformasi yang signifikan. Transformasi ekonomi dibanyak negara Asian sudah berpindah dari pertanian ke sektor jasa. Sektor jasa merupakan sektor terbesar dibanyak ekonomi, namun sulit untuk dianalisis karena sifatnya yang sangat heterogen. Produktivitas sektor jasa yang semakin tinggi berkaitan dengan urbanisasi (ADB, 2013).

Menurut Timmer \& Akkus (dalam Wuyts \& Kilama, 2014), ada empat proses yang saling terkait dan terus-menerus yang dapat mendefinisikan transformasi struktural:

1) Kontribusi pertanian yang menurun dalam PDB dan lapangan kerja,

2) Migrasi dari daerah pedesaan ke perkotaan dan proses urbanisasi yang cepat,

3) Meningkatnya industri modern dan ekonomi sektor jasa,

4) Transisi demografi dari tingkat kelahiran dan kematian yang tinggi menjadi tingkat kelahiran dan kematian rendah (berhubungan dengan standard kesehatan daerah perkotaan yang lebih baik.

Oleh karena itu, kunci dari proses transformasi ekonomiterletak pada keterkaitan antara pertanian pada di satu sisidan industri dan jasa di sisi lain. 


\section{Pariwisata}

Menurut United Nations World Tourism Organization(UNWTO), pariwisata terdiri dari kegiatan orang-orang yang bepergian ke dan tinggal di tempat-tempat di luar lingkungan biasa selama tidak lebih dari satu tahun berturut-turut untuk liburan, bisnis dan keperluan lainnya yang tidak terkait dengan pelaksanaan suatu kegiatan yang digaji dari tempat yang dikunjungi (Shukla \& Ansari, 2013). Pariwisata merupakan usaha yang melakukan banyak aktivitas, seperti usaha yang menyediakan jasa akomodasi, restoran, angkutan, atraksi pariwisata, jasa perdagangan eceran, jasa taksi, dan lain-lain. Pariwisata ini didefinisikan oleh aktivitas tipe konsumen tertentu, dan bukan oleh jenis penyedia/supplier tertentu. Selain itu, UNWTO juga menyebutkan bahwa pariwisata adalah sebuah fenomena sosial, budaya, dan ekonomi yang memerlukan pergerakan seseorang ke suatu negara atau tempat diluar lingkungan mereka yang biasa untuk tujuan pribadi maupun bisnis.

Menurut Undang-Undang Republik Indonesia Nomor 10 Tahun 2009, wisata adalah kegiatan perjalanan yang dilakukan oleh seseorang atau sekelompok orang dengan mengunjungi tempat tertentu untuk tujuan rekreasi, pengembangan pribadi, atau mempelajari keunikan daya tarik wisata yang dikunjungi dalam jangka waktu sementara. Sedangkan, pariwisata adalah berbagai macam kegiatan wisata dan didukung berbagai fasilitas serta layanan yang disediakan oleh masyarakat, pengusaha, Pemerintah, dan Pemerintah Daerah.

Beberapa alasan mengapa ilmuwan regional harus mempertimbangkan pariwisata sebagai area studi (Sam Cole, 2007).

1) Importance: Pariwisata saat ini menjadi salah satu industri terbesar di dunia dan salah satu industri yang berkembang paling cepat.

2) Regional: Pariwisata adalah aktivitas regional pada seluruh skala, dari kelompok usaha kecil sampai pada operasi global rantai utama, maskapai penerbangan, dan organisasi internasional.

3) Fields and topic: Sebagian besaryang dipelajari ilmuwan regional sangat penting bagi analisis pariwisata, secara langsung atau tidak langsung.

4) Issues: Banyak pertanyaan terkait sisi kebijakan publik dan bisnis industri yang dapat diatasi dengan metode spasial, temporal, dan struktural yang telah dikembangkan oleh ilmuwan regional selama setengah abad terakhir.

5) Disciplines:Mengatasi ilmu pengetahuan daerah untuk studi pariwisata dapat mendorong aspirasi untuk menjadi disiplin integratif.

6) Data: Karena industri ini cukup dimonitor secara hati-hati, maka ada kesempatan empiris untuk menguji keberadaan dan teori baru pariwisata, serta teori yang terintegrasidengan demografi, makroekonomi, dan sistem lingkungan.

7) Theory: Topiknya cocok dengan tantangan teoritis dan analitik baru, terutama teori dikotomi global-lokal, evolusioner, dan kompleksitas, serta agen - model yang digerakan.

8) Resources: Sebagai industri yang berkembang di seluruh dunia, terutama di daerah yang berkembang pesat, lapangan ini menyediakan lebih banyak kesempatan untuk pendanaan penelitian.

9) Need:Ada kebutuhan nyata untuk analisis berorientasi kebijakan publik.

\section{Keterkaitan Sektor Pariwisata terhadap Perekonomian}

Sektor pariwisata memiliki peran penting secara tidak langsung dengan melengkapi faktor produksi lainnya dalam proses pertumbuhan ekonomi (Tugcu, 2014). Dalam analisis pariwisata, para ekonom menekankan dampak pengembangan pariwisata terhadap perekonomian. Hal ini dikarenakan pariwisata merupakan kegiatan multidisipliner yang melibatkan beberapa industri dan 
memanfaatkan beragam keterampilan, serta manfaatnya tersebar di sebagian besar masyarakat secara relatif ke sektor ekonomi lainnya(Telce \& Schroenn, 2006). Selain itu, keunggulan sektor pariwisata adalah cenderung padat karya, sehingga peningkatan produksi biasanya dicapai dengan kenaikan lapangan kerja. Hal ini menguntungkan bagi ekonomi yang perlu mengurangi tingkat pengangguran, meskipun juga menimbulkan shock di pasar kerja dimana akan menaikkan upah di sektor jasa dan mendorong mobilitas lintas sektoral (Akan et al, 2007).Tidak seperti sektor lain yang bersifat daerah kantong (enclave), seperti sektor ekstraktif, pariwisata menciptakan keterkaitan antar sektor dalam ekonomi, sehingga sektor ini lebih cenderung berkontribusi pada diversifikasi ekonomi (United Nations, 2013).

Pariwisata merupakan penggerak perkembangan ekonomi dan sosial yang signifikan (Baker, 2014). Sektor ini dapat menstimulasi pertumbuhan ekonomi dengan meningkatkan pendapatan, tenaga kerja, investasi, dan ekspor. World Travel and Tourism Council bersama dengan Oxford Economics telah mengembangkan pendekatan pengukuran kontribusi perjalanan dan pariwisata terhadap Produk Domestik Bruto (PDB) dan tenaga kerja yang terdiri dari kontribusi langsung, tidak langsung, dan dipaksakan (induced) (Athanasopoulou, 2013).

Kontribusi langsung perjalanan dan pariwisata mencakup total pengeluaran di negara tertentu dalam perjalanan dan pariwisata oleh resident dan non residen untuk bisnis dan waktu luang. Dalam pendekatan ini juga termasuk pengeluaran pemerintah dalam perjalanan dan pariwisata yang berhubungan dengan pengunjung (contoh: museum, taman nasional, dll). Kontribusi tidak langsung mengarah pada investasi, pembelian barang dan jasa dengan sektor yang berhubungan langsung dengan wisatawan (seperti pembelian jasa kebersihan di hotel). Pendekatan selanjutnya adalah kontribusi yang dipaksakan mencakup pengeluaran oleh mereka yang secara langsung atau tidak langsung bekerja di sektor perjalanan dan pariwisata. Pada Gambar 2 terlihat cakupan dari masingmasing kontribusi di atas.

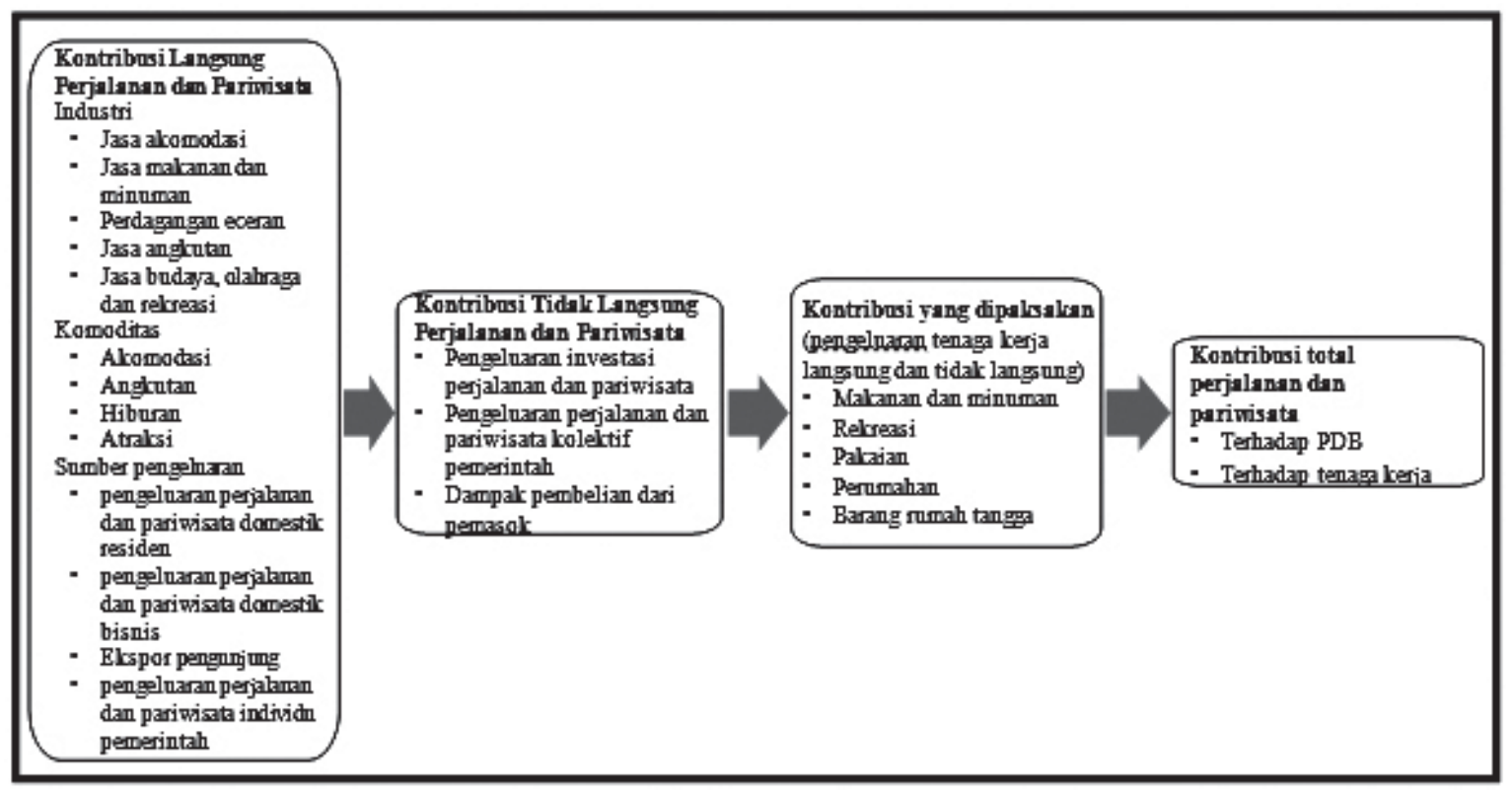

Sumber: World Travel and Tourism Council and Oxford Economics (dalam

Athanasopoulou,2013)

Gambar 2.

Kontribusi Ekonomi Perjalanan dan Pariwisata 
Peran sektor pariwisata yang berpengaruh dalam aspek ekonomi dan sosial ini tidak lepas dari kontribusinya dalam pengurangan kemiskinan di suatu wilayah. ODI World Bank mengidentifikasi tiga jalur utama pariwisata dalam mempengaruhi pengurangan kemiskinan (Ashley et al, 2007).

- Dampak langsung pariwisatameliputi upah dan gaji seseorang yang berpartisipasi secara langsung dalam sektor pariwisata,baik sebagai pekerja maupun pengusaha. Bukti internasional menunjukkan bahwa pariwisata merupakan sektor yang lebih padat karya dibanding pertanian. Secara keseluruhan, sektor ini juga menggunakan proporsi yang besar untuk tenaga tanpa keterampilan dan yang semi terampil. Untuk alasan tersebut, di beberapa negara, pariwisata adalah sumber penting tenaga kerja untuk masyarakat miskin.

- Dampak tidak langsung pariwisataterjadi melalui rantai nilai pariwisata. Pariwisata mengacu pada input dari makanan dan minuman, konstruksi, angkutan, perabotan, dan banyak sektor lainnya. Bukti menunjukkan bahwa di negara berkembang, dampak antar sektor ini menambah 60-70\% di atas dampak langsung pariwisata.

- Ketiga adalah dampak dinamis. Perkembangan pariwisata dapat mempengaruhi strategi kehidupan rumah tangga lokal, perkembangan iklim usaha kecil, pola pertumbuhan ekonomi lokal dan nasional, serta infrastruktur atau sumber data alam tujuan. Pariwisata juga cenderung mempekerjakanwanita dalam proporsi yang besar dan membeli produk yang diproduksi oleh wanita pada sektor informal, seperti makanan dan kerajinan. Hasilnya, sektor ini dapat meningkatkan posisi wanita dalam perekonomian dan membantu mengatasi beban jenis kelamin. Selain itu dalam beberapa lokasi, sektor pariwisata memiliki peran penting dalam perencanaan dan menanggapi bencana alam, yang sering kali berdampak negatif terhadap masyarakat miskin.

\section{Penelitian Terkait}

Penelitian yang berkaitan dengan pariwisata cukup banyak menarik perhatian para peneliti. Beberapa penelitiannya adalah sebagai berikut.

Penelitian yang berjudul Tourism Development and Economic Growth in Developing Countriesoleh Ekanayake dan Long (2012) membahas tentang hubungan perkembangan pariwisata dan pertumbuhan ekonomi di negara berkembang menggunakan metode kointegrasi panel heterogen yang baru dikembangkan. Studi ini menguji hubungan kausalitas antara perkembangan pariwisata dan pertumbuhan ekonomi dengan menggunakan uji kausalitas Granger pada model mutivariat dan menggunakan data tahunan 1995 - 2009. Hasilnya menunjukkan bahwa pemerintah negara berkembang seharusnya berfokus pada kebijakan ekonomi yang mempromosikan pariwisata sebagai sumber potensial pertumbuhan ekonomi.

Penelitian yang berjudul Tourism Development Effect on Saudi Economic Diversification oleh Yousif dan Bakr (2017) bertujuan untuk mengestimasi dampak sektor pariwisata terhadap output, pendapatan, dan tenaga kerja. Penelitian ini menggunakan analisis input output. Hasil penelitiannya menunjukkan bahwa sektor pariwisata memiliki dampak ekonomi langsung dan tidak langsung yang positif. Dampak langsung sebagian besar berasal dari aktivitas pariwisata itu sendiri. Sedangkan, dampak tidak langsung berasal dari sektor produksi lainnya, seperti sektor jasa, konstruksi, dan industri pengolahan.

Penelitian yang berjudul Tourism And Economic Growth In Malaysia: Cointegration And Causality Analysis oleh Qaiser Munir et al (2015) bertujuan untuk mengetahui hubungan antara aktivitas pariwisata dan pertumbuhan ekonomi. Hubungan yang akan diuji adalah apakah aktivitas pariwisata yang mendorong pertumbuhan ekonomi atau sebaliknya perkembangan ekonomi 
yang mendorong pertumbuhan pariwisata atau kemungkinan lain yaitu ada hubungan dua arah antara dua variabel tersebut. Studi ini menggunakan metode Autoregressive Distributed Lag $(A R D L)$ dimana hasilnya menunjukkan ada hubungan dua arah antara aktivitas pariwisata dan pertumbuhan ekonomi.

Penelitian yang berjudul Tourism and Economic Growth Nexus: an input output analysis in Turkey oleh Sibel Atan dan Yalcin Arslanturk (2012) membahas tentang hubungan antara pariwisata dan pertumbuhan ekonomi dengan menggunakan analisis input output mencakup dampak keterkaitan ke depan dan ke belakang. Variabel yang digunakan untuk pertumbuhan ekonomi adalah pendapatan dan output produksi. Sedangkan, pariwisata diklasifikasi sebagai hotel dan restoran dan aktivitas penunjang transportasi; aktivitas sektor agen travel; aktivitas rekreasi, budaya dan olahraga.

Penelitian yang berjudulEconomic Impact from Development of the Coastal Town in Quensland on Tourism and Regional Economyoleh Galina Williams (2016) mendiskusikan bagaimana cara untuk menciptakan kesempatan industri pariwisata untuk terintegrasi dengan lebih baik terhadap ekonomi regional. Alat analisis yang digunakan adalah analisis input output. Pada penelitian ini sektor yang dipertimbangkan sebagai sektor yang berkaitan dengan pariwisata adalah perdagangan eceran; jasa akomodasi dan makan minum; transportasi, pos dan pergudangan; jasa persewaan dan real estate; jasa administratif dan pendukung; dan jasa kesenian dan rekreasi.

Penelitian yang berjudul Analisis Input-Output atas Dampak Sektor Pariwisata terhadap Perekonomian Maluku oleh Eldo Malba dan Iqbal M. Taher (2016) membahas mengenai peran sektor pariwisata dalam perekonomian Provinsi Maluku dengan menggunakan model input output. Cakupan sektor yang dikategorikan penelitian ini sebagai sektor pariwisata adalah hotel dan restoran; angkutan air; angkutan udara; dan jasa-jasa lainnya.

\section{HASIL DAN PEMBAHASAN}

\section{Sektor Pariwisata Provinsi Kalimantan Selatan}

Kalimantan Selatan merupakan provinsi yang beribukota Banjarmasin. Luas wilayah provinsi ini adalah sekitar 37.530,52 km² atau 6,98 persen dari luas Pulau Kalimantan dan 1,96 persen dari luas wilayah Indonesia (BPS, 2017). Gambaran Kalimantan Selatan erat dengan sungai dan tanah rawanya.Sehingga keunggulan tersebut dapat dijadikan sebagai sumber pariwisata. Saat ini, pemerintah mulai mengembangkan perbaikan infrastruktur terkait sungai untuk menunjang pariwisata tersebut. Selain hal tersebut, budaya dari Kalimantan Selatan dapat juga menjadi daya tarik wisatawan untuk menunjang sektor pariwisata. Budaya tersebut dapat ditampilkan dalam bentuk karnaval, pagelaran seni, dan upacara adat yang disediakan untuk publik. Selain objek pariwisata itu sendiri, faktor penunjang lainnya juga diperlukan, yaitu terkait kuliner dan produk keterampilan. Hal ini juga dapat dikembangkan di Kalimantan Selatan dimana kuliner dan produk keterampilan di provinsi ini cukup banyak dan memiliki ciri khasnya tersendiri.

Jika dilihat berdasarkan jumlah wisatawan yang berkunjung ke Kalimantan Selatan yang ditampilkan dalam Tabel 1, terlihat bahwa setiap tahunnya terjadi peningkatan jumlah wisatawan baik dari manca negara maupun nusantara. Bahkan pada tahun 2016, peningkatan jumlah wisatawan mencapai 9 persen. Hal ini menunjukkan bahwa daya tarik pariwisata Kalimantan Selatan setiap tahunnya mengalami peningkatan di mata para wisatawan. 
Tabel 1.

Jumlah Wisatawan yang Berkunjung di Provinsi Kalimantan Selatan Tahun 2011-2016

\begin{tabular}{|c|c|c|c|c|c|c|}
\hline Tahun & $\mathbf{2 0 1 1}$ & $\mathbf{2 0 1 2}$ & $\mathbf{2 0 1 3}$ & $\mathbf{2 0 1 4}$ & $\mathbf{2 0 1 5}$ & \multicolumn{1}{|c|}{$\mathbf{2 0 1 6}$} \\
\hline$(1)$ & $(2)$ & $(3)$ & $(4)$ & $(5)$ & $(6)$ & $(7)$ \\
\hline Manca Negara & 24.869 & 25.220 & 25.435 & 26.395 & 26.934 & 27.742 \\
\hline Nusantara & 502.046 & 517.197 & 540.906 & 597.324 & 627.853 & 690.638 \\
\hline Jumlah & $\mathbf{5 2 6 . 9 1 5}$ & $\mathbf{5 4 2 . 4 1 7}$ & $\mathbf{5 6 6 . 3 4 1}$ & $\mathbf{6 2 3 . 7 1 9}$ & $\mathbf{6 5 4 . 7 8 7}$ & $\mathbf{7 1 8 . 3 8 0}$ \\
\hline
\end{tabular}

Sumber: BPS Provinsi Kalimantan Selatan, 2017

\section{Analisis Sektor Pariwisata terhadap Perekonomian Provinsi Kalimantan Selatan}

Untuk melakukan analisis yang rinci terkait pengaruh sektor pariwisata terhadap perekonomian Kalimantan Selatan, alat yang digunakan adalah tabel input output. Dari tabel tersebut, akan diperoleh gambaran mengenai keterkaitan antar sektor, baik keterkaitan ke belakang (daya penyebaran) maupun keterkaitan ke depan (derajat kepekaan). Selain itu, untuk melihat dampak perubahan atau peningkatan permintaan akhir setiap satu satuan terhadap semua sektor dapat dianalisis menggunakan analisis dampak. Analisis dampak ini dapat dijabarkan dalam analisis pengganda output dan NTB.

\section{Analisis Daya Penyebaran}

Daya penyebaran atau yang biasa disebut sebagai keterkaitan ke belakang (backward linkage) menunjukkan pengaruh terhadap kinerja sektor lainnya. Secara matematis, besaran daya penyebaran merupakan jumlah dampak yang ditimbulkan akibat perubahan permintaan akhir suatu sektor terhadap output seluruh sektor ekonomi di suatu wilayah(BPS, 2011). Berikut tabel yang menunjukkan nilai daya penyebaran dan indeksnya pada 11 sektor ekonomi dalam tabel input output.

Berdasarkan Tabel 2, daya penyebaran sektor pariwisata masih tergolong di bawah rata-rata daya penyebaran seluruh sektor ekonomi di Kalimantan Selatan. Dengan kata lain, peningkatan sektor pariwisata di Kalimantan Selatan kurang mendorong peningkatan output sektor lain yang menjadi input dari sektor pariwisata tersebut. Hal ini ditunjukkan dari nilai indeks daya penyebarannya di bawah satu, yaitu 0,937. Daya penyebaran sektor pariwisata yangsebesar1,839menunjukkan bahwajika permintaanakhir pada sektor pariwisata meningkat satu miliar rupiah, maka output kegiatan ekonomi secara total akan meningkat sebesar Rp 1,839 miliar. Peningkatan sektor pariwisata ini akan meningkatkan output ekonomi secara total hampir dua kali dari permintaan itu sendiri. 
Tabel 2.

Daya Penyebaran dan Indeksnya pada Sektor Ekonomi Provinsi Kalimantan Selatan Tahun 2010

\begin{tabular}{|c|l|c|c|}
\hline Sektor & \multicolumn{1}{|c|}{ Keterangan } & $\begin{array}{c}\text { Indeks Daya } \\
\text { Penyebaran }\end{array}$ & $\begin{array}{c}\text { Daya } \\
\text { Penyebaran }\end{array}$ \\
\hline $\mathbf{1}$ & Pertanian, Kehutanan, dan Perikanan & 0,764 & 1,500 \\
\hline $\mathbf{2}$ & Pertambangan dan Penggalian & 0,899 & 1,766 \\
\hline $\mathbf{3}$ & Industri Pengolahan & 1,172 & 2,302 \\
\hline $\mathbf{4}$ & Listrik & 1,245 & 2,444 \\
\hline $\mathbf{5}$ & Air Minum & 1,091 & 2,142 \\
\hline $\mathbf{6}$ & Bangunan & 1,169 & 2,296 \\
\hline $\mathbf{7}$ & Pariwisata & 0,937 & 1,839 \\
\hline $\mathbf{8}$ & Komunikasi & 0,810 & 1,591 \\
\hline $\mathbf{9}$ & Lembaga Keuangan, Usaha Persewaan dan & 0,896 & 1,760 \\
\hline $\mathbf{1 0}$ & $\begin{array}{l}\text { Jasa Perusahaan; Jasa Pemerintahan dan } \\
\text { Pertahanan }\end{array}$ & 0,896 & 2,143 \\
\hline $\mathbf{1 1}$ & Kemasyarakatan & 1,091 & 1,814 \\
\hline
\end{tabular}

Jika dikaji lebih dalam untuk sektor pariwisata, subsektor angkutan, restoran/rumah makan, dan jasa hiburan dan rekreasi memiliki indeks daya penyebaran yang tinggi, yaitu di atas satu.Sehingga, dengansektor pariwisata di Kalimantan Selatan yang berfokus pada ketiga subsektor tersebut akan dapat mendorong peningkatan sektor ekonomi secara keseluruhan.

Tabel 3.

Daya Penyebaran dan Indeksnya pada Sektor Pariwisata Provinsi Kalimantan Selatan Tahun 2010

\begin{tabular}{|c|l|c|c|}
\hline No. & \multicolumn{1}{|c|}{ Subsektor } & $\begin{array}{c}\text { Indeks Daya } \\
\text { Penyebaran }\end{array}$ & Daya Penyebaran \\
\hline$(1)$ & \multicolumn{1}{|c|}{$(2)$} & $(3)$ & $(4)$ \\
\hline $\mathbf{l}$ & Perdagangan & 0,851 & 1,650 \\
\hline $\mathbf{2}$ & Jasa Akomodasi & 0,971 & 1,883 \\
\hline $\mathbf{3}$ & Restoran/Rumah Makan & 1,112 & 2,156 \\
\hline $\mathbf{4}$ & Angkutan & 1,215 & 2,356 \\
\hline $\mathbf{5}$ & $\begin{array}{l}\text { Jasa Penunjang Angkutan dan } \\
\text { Pergudangan }\end{array}$ & 0,925 & 1,794 \\
\hline $\mathbf{6}$ & Jasa Hiburan dan Rekreasi & 1,065 & 2,065 \\
\hline
\end{tabular}

\section{Analisis Derajat Kepekaan}

Daya kepekaan atau dikenal juga sebagai keterkaitan ke depan (forward linkage) berguna untuk mengukur seberapa jauh suatu sektor dipengaruhi oleh perubahan permintaan akhir masingmasing sektor ekonomi (BPS, 2011).Berbeda dengan indeks dayapenyebarannya, nilai indeks 
derajatkepekaan sektor pariwisata berada di atas satu $(1,443)$ yang berarti derajat kepekaan sektor pariwisata di atas rata-rata derajat kepekaan seluruh sektor ekonomi.Nilai indeks derajat kepekaan yang tinggi ini juga dibuktikan secara empiris dalam penelitian Kweka et al (2003) yang dilakukan di Tanzania. Dalam penelitian tersebut menyimpulkan bahwa semakin berkembang sektor pariwisata, maka meningkat pula penggunaan jasa sektor tersebut dalam sektor lainnya.

Tabel 4.

Derajat Kepekaan dan Indeksnya pada Sektor Ekonomi di Provinsi Kalimantan Selatan

Tahun 2010

\begin{tabular}{|c|l|c|c|}
\hline Sektor & \multicolumn{1}{|c|}{ Keterangan } & $\begin{array}{c}\text { Indeks Derajat } \\
\text { Kepekaan }\end{array}$ & $\begin{array}{c}\text { Derajat } \\
\text { Kepekaan }\end{array}$ \\
\hline $\mathbf{1})$ & \multicolumn{1}{|c|}{$(2)$} & $(3)$ & $(4)$ \\
\hline $\mathbf{1}$ & Pertanian, Kehutanan, dan Perikanan & 1,626 & 3,193 \\
\hline $\mathbf{2}$ & Pertambangan dan Penggalian & 0,720 & 1,413 \\
\hline $\mathbf{3}$ & Industri Pengolahan & 2,465 & 4,840 \\
\hline $\mathbf{4}$ & Listrik & 0,676 & 1,327 \\
\hline $\mathbf{5}$ & Air Minum & 0,657 & 1,289 \\
\hline $\mathbf{6}$ & Bangunan & 0,628 & 1,232 \\
\hline $\mathbf{7}$ & Pariwisata & 1,443 & 2,834 \\
\hline $\mathbf{8}$ & Komunikasi & 0,616 & 1,210 \\
\hline $\mathbf{9}$ & Lembaga Keuangan, Usaha Persewaan dan Jasa & 1,044 & 2,051 \\
\hline $\mathbf{1 0}$ & Jerusahaan; Jasa Pemerintahan dan Pertahanan & 0,611 & 1,200 \\
\hline $\mathbf{1 1}$ & Kegiatan yang tidak jelas batasannya & 0,513 & 1,008 \\
\hline
\end{tabular}

Derajat kepekaan sektor pariwisata yang sebesar 2,834 mengartikan bahwa peningkatan permintaan akhir seluruh sektor ekonomi sebesar satu miliar rupiah, maka akan menyebabkan peningkatan output sektor pariwisata sebesar Rp 2,834 miliar. Hal ini menunjukkan bahwa peningkatan seluruh sektor akan meningkatkanhampir tiga kali sektor pariwisata di Kalimantan Selatan.

Tabel 5.

Derajat Kepekaan dan Indeksnya pada Sektor Pariwisata Provinsi Kalimantan Selatan Tahun 2010

\begin{tabular}{|c|l|c|c|}
\hline No. & \multicolumn{1}{|c|}{ Subsektor } & $\begin{array}{c}\text { Indeks Derajat } \\
\text { Kepekaan }\end{array}$ & Derajat Kepekaan \\
\hline$(1)$ & \multicolumn{1}{|c|}{$(2)$} & $(3)$ & $(4)$ \\
\hline $\mathbf{1}$ & Perdagangan & 1,042 & 2,020 \\
\hline $\mathbf{2}$ & Jasa Akomodasi & 0,541 & 1,049 \\
\hline $\mathbf{3}$ & Restoran/Rumah Makan & 0,587 & 1,137 \\
\hline $\mathbf{4}$ & Angkutan & 1,058 & 2,050 \\
\hline $\mathbf{5}$ & $\begin{array}{l}\text { Jasa Penunjang Angkutan dan } \\
\text { Pergudangan }\end{array}$ & 0,634 & 1,230 \\
\hline $\mathbf{6}$ & Jasa Hiburan dan Rekreasi & 0,601 & 1,165 \\
\hline
\end{tabular}


Jika sektor pariwisata dirinci lebih detail, subsektor yang memiliki derajat kepekaan yang cukup tinggi adalah sektor angkutan dan perdagangan. Indeks derajat kepekaan kedua subsektor tersebut berada di atas satu, yaitu masing-masing sebesar 1,058 dan 1,042. Pada sektor pariwisata ini, subsektor yang memiliki indeks daya penyebaran dan derajat kepekaan lebih dari satu adalah subsektor angkutan. Sehingga untuk pariwisata di Kalimantan Selatan, yang memiliki dorongan kuat ke depan maupun kebelakang terhadap sektor lain adalah dari subsektor angkutan tersebut.

\section{Analisis Dampak}

\section{Dampak Output}

Analisis dampak output ini adalah untuk memperlihatkan pengaruh komponen permintaan akhir terhadap pembentukan output suatu sektor. Pada tabel di bawah ini ditunjukkan besaran nilai dampak output untuk masing-masing sektor pariwisata secara parsial.

Tabel 6.

Dampak Permintaan Akhir terhadap Output Masing-masingSektor Pariwisata

\begin{tabular}{|c|l|c|c|}
\hline No. & \multicolumn{1}{|c|}{ Subsektor } & Output (Miliar Rp) & Prioritas \\
\hline$(1)$ & \multicolumn{1}{|c|}{$(2)$} & $(3)$ & $(4)$ \\
\hline $\mathbf{1}$ & Perdagangan & 16.092 & 2 \\
\hline $\mathbf{2}$ & Jasa Akomodasi & 610 & 5 \\
\hline $\mathbf{3}$ & Restoran/Rumah Makan & 17.500 & 3 \\
\hline $\mathbf{4}$ & Angkutan & 1.453 & 1 \\
\hline $\mathbf{5}$ & $\begin{array}{l}\text { Jasa Penunjang Angkutan dan } \\
\text { Pergudangan }\end{array}$ & 266 & 4 \\
\hline $\mathbf{6}$ & Jasa Hiburan dan Rekreasi & & 6 \\
\hline
\end{tabular}

Berdasarkan tabel di atas, sektor pariwisata yang memiliki nilai dampak output terbesar adalah subsektor angkutan.Hasil ini sesuai dengan penelitian yang dilakukan oleh Tantri Tantirigama \& Mei Taniguchi-Singh (2009) dan Eldo Malba dan Iqbal M. Taher (2012) dimana angka multipier output angkutan lebih besar dibanding subsektor pariwisata lainnya. Angka output 17.570 memiliki makna bahwa apabila terjadi peningkatan permintaan akhir di subsektor angkutan sebesar satu rupiah, maka output di semua sektor perekonomian Kalimantan Selatan akan bergerak meningkat sebesar Rp 17.570 miliar.Begitu pula untuk perdagangan, sektor pariwisata tersebut juga memiliki pengaruh terhadap output keseluruhan ekonomi yang cukup besar. Sehingga, akan menjadi hal yang tepat jika pemerintah akan meningkatkan sektor pariwisata adalah dengan berfokus kepada ketiga subsektor prioritas, yaitu sektor angkutan, perdagangan, dan restoran/rumah makan.

\section{Dampak NTB}

Analisis dampakNTB bergunamengukur peningkatan pendapatan akibat adanya perubahan output dalam perekonomian. Tabel di bawah ini menjabarkan nilai dampak pendapatan secara parsial untuksektor pariwisata. 
Tabel 7.

Dampak Permintaan Akhir terhadap NTB Masing-masing Sektor Pariwisata

\begin{tabular}{|c|l|r|c|}
\hline No. & \multicolumn{1}{|c|}{ Subsektor } & $\begin{array}{c}\text { NTB } \\
\text { (Miliar Rp) }\end{array}$ & Prioritas \\
\hline$(1)$ & \multicolumn{1}{|c|}{$(2)$} & $(3)$ & $(4)$ \\
\hline $\mathbf{1}$ & Perdagangan & 10.787 & 1 \\
\hline $\mathbf{2}$ & Jasa Akomodasi & 343 & 5 \\
\hline $\mathbf{3}$ & Restoran/Rumah Makan & 1.444 & 3 \\
\hline $\mathbf{4}$ & Angkutan & 6.411 & 2 \\
\hline $\mathbf{5}$ & $\begin{array}{l}\text { Jasa Penunjang Angkutan dan } \\
\text { Pergudangan }\end{array}$ & 855 & 4 \\
\hline $\mathbf{6}$ & Jasa Hiburan dan Rekreasi & 127 & 6 \\
\hline
\end{tabular}

Seperti halnya nilai dampak output, sektor pariwisata yang mendominasi dampak NTB adalah subsektor perdagangan, angkutan, dan restoran/rumah makan. Untuk subsektor perdagangan, nilai dampaknya adalah sebesar Rp 10.787 miliar yang berarti setiap peningkatan permintaan akhir di subsektor perdagangan senilai satu rupiah, maka akan menyebabkan pertambahan NTB senilai Rp 10.787 miliar. Begitu pula makna yang dapat diambil dari nilai dampak subsektor angkutan dan restoran/rumah makan yang masing-masing sebesar Rp 6.411 miliar dan Rp 1.444 miliar. Ketiga subsektor tersebut dapat menjadi fokus utama pemerintah saat akan membuat kebijakan terkait pariwisata dengan tujuan untuk meningkatkan pendapatan di Kalimantan Selatan.

\section{Kesiapan Sektor Pariwisata sebagai Sektor Ekonomi Unggulan}

Untuk mengetahui tingkat kesiapan sektor pariwisata dijadikan sebagai sektor unggulan di Kalimantan Selatan, dapat dilakukan analisis dari indeks daya penyebaran dan derajat kepekaan yang sudah dihitung sebelumnya. Sektor unggulan adalah sektor yang dapat meningkatkan stimulus perekonomian suatu wilayah melebihi rata-rata sektor lainnya (Galina Williams, 2016).Suatu sektor dapat dikatakan sektor kunci atau unggulan dalam suatu wilayah jika memiliki nilai lebih dari satu untuk kedua indeks tersebut.

Tabel 8.

Indeks Daya Penyebaran dan Derajat Kepekaan Sektor Pariwisata di Provinsi Kalimantan Selatan Tahun 2010

\begin{tabular}{|c|l|c|c|}
\hline No. & \multicolumn{1}{|c|}{ Sektor } & $\begin{array}{c}\text { Indeks Daya } \\
\text { Penyebaran }\end{array}$ & $\begin{array}{c}\text { Indeks Derajat } \\
\text { Kepekaan }\end{array}$ \\
\hline$(1)$ & \multicolumn{1}{|c|}{$(2)$} & $(3)$ & $(3)$ \\
\hline $\mathbf{1}$ & Perdagangan & 0,851 & 1,042 \\
\hline $\mathbf{2}$ & Jasa Akomodasi & 0,971 & 0,541 \\
\hline $\mathbf{3}$ & Restoran/Rumah Makan & 1,112 & 0,587 \\
\hline $\mathbf{4}$ & Angkutan & 1,215 & 1,058 \\
\hline $\mathbf{5}$ & $\begin{array}{l}\text { Jasa Penunjang Angkutan dan } \\
\text { Pergudangan }\end{array}$ & 0,925 & 0,634 \\
\hline $\mathbf{6}$ & Jasa Hiburan dan Rekreasi & 1,065 & 0,601 \\
\hline
\end{tabular}


Dari hasil indeks tersebut pada Tabel 8, ditampilkan bahwa sektor pariwisata memiliki indeks daya penyebaran di bawah satu dan indeks derajat kepekaan di atas satu. Meskipun daya penyebarannya di bawah rata-rata, namun perlu diperhatikan bahwa indeksnya mendekati angka satu yang artinya keterkaitan ke belakangnya cukup besar meskipun tidak dapat dikatakan sangat kuat.Sehingga dapat dikatakan peran sektor pariwisata memiliki potensi untuk mendorong sektor ekonomi lainnya baik dari segi input maupun outputnya.Jika diperhatikan lebih rinci, sektor pariwisata yang berpotensi besar untuk menjadi sektor kunci adalah subsektor angkutan. Karena subsektor tersebutlah yang memiliki nilai indeks daya penyebaran dan derajat kepekaan lebih dari satu. Penelitian yang dilakukan oleh Hassan \& Jenggie (2012) juga menunjukkan hasil yang bersesuaian dimana dari sektor pariwisata hanya subsektor angkutan yang memiliki nilai indeks daya penyebaran dan derajat kepekaan yang lebih dari satu.

\section{E. PENUTUP}

\section{Kesimpulan dan Saran}

Berdasarkan pembahasan di atas, dapat disimpulkan bahwa sektor pariwisata memiliki keterkaitan yang erat ke depan (derajat kepekaan) yang berarti dengan adanya peningkatan output keseluruhan sektor di Kalimantan Selatan, maka sektor pariwisata akan semakin berkembang. Begitu pula untuk keterkaitan ke belakang (daya penyebaran), sektor pariwisata memiliki keterkaitan yang erat meskipun tidak terlalu kuat untuk mendorong peningkatan seluruh sektor ekonomi. Berdasarkan indeks daya penyebaran dan derajat kepekaan, sektor pariwisata cukup siap untuk menjadi sektor kunci atau unggulan di Kalimantan Selatan, terutama jika berfokus pada subsektor angkutan yang menjadi prioritas dalam sektor pariwisata itu sendiri. Hal ini karena angkutan merupakan sektor yang membuka akses wisatawan untuk berkunjung ke suatu wilayah. Sehingga, perbaikan dan pengembangan dalam subsektor ini akan memberikan pengaruh yang besar baik terhadap input maupun output seluruh ekonomi di Kalimantan Selatan.

Berdasarkan hasil penelitian di atas, untuk meningkatkan output maupun pendapatan melalui sektor pariwisata yang dapatmenjadi fokus kebijakan pemerintah Kalimantan Selatan adalah pada subsektor angkutan, perdagangan, dan restoran/rumah makan. Ketiga subsektor tersebut menjadi tumpuan besarnya pengaruh sektor pariwisata terhadap perekonomian Kalimantan Selatan. Seperti disebutkan sebelumnya, subsektor angkutan menjadi pintu gerbang utama dalam hal akses ke objek pariwisata. Subsektor perdagangan menjadi daya tarik dalam hal perdagangan produk kerajinan yang menjadi ciri khas Kalimantan Selatan. Subsektor restoran/rumah makan dapat menjadi unggulan dengan meningkatkan kreasi kuliner yang ada di provinsi tersebut.

\section{DAFTAR PUSTAKA}

Akan, Yusuf. Arslan, I. \& Cem Is K. (2007). The Impact of Tourism on Economic Growth: The Case of Turkey. Journal of Tourism. Vol IX. 1-24.

Atan, Sibel. \&Arslanturk, Yalcin. (2012). Tourism and Economic Growth Nexus: an input output analysis in Turkey.Elsevier. 62. 952 - 956.

Ashley, Caroline. et al. (2007). The Role of The Tourism Sector in Expanding Economic Opportunity. Corporate Social Responsibility Initiative Report No 23. Cambridge. The Fellows of Harvard College, Overseas Development Institute, International Business Leader Forum. 
Asian Development Bank. (2013). Asia's Economic Transformation: Where to, How, and How Fast?. Philippines. Asian Development Bank.

Athanasoupoulou, Anna. (2013). Tourism as a driver of economic growth and development in the EU-27 and ASEAN regions. EU Centre in Singapore.

Badan Pusat Statistik.(2010). Tabel InputOutput 2010 Kalimantan Selatan. Banjarmasin. BPS Provinsi Kalimantan Selatan.

Badan Pusat Statistik. (2017). Provinsi Kalimantan Selatan Dalam Angka. Banjarbaru. BPS Provinsi Kalimantan Selatan.

Badan Pusat Statistik.(2017). Produk Domestik Regional Bruto Kabupaten/Kota di Kalimantan Selatan Menurut Lapangan Usaha 2012-2016. Banjarbaru. BPS Provinsi Kalimantan Selatan.

Baker, David Mc.A. (2014). The Effects of Terrorism on the Travel and Tourism Industry. International Journal of Religious Tourism and Pilgrimage. 2. 558-67.

Breisinger, Clemens. \&Diao, Xinshen. (2008). Economic Transformation in Theory and Practice: What are the Messages for Africa?. International Food Policy Research Institute Discussion Paper 00797. 1 - 50.

Cole, Sam. (2007). The Regional Science of Tourism: An Overview. The Journal of Regional Analysis \& Policy. 37 (3). 183 - 192.

Ekanayake, E.M. \&Long, Aubrey E. (2012). Tourism Development and Economic Growth in Developing Countries. IJBFR. 1. 51 - 63.

Hasan, Mohd Khairul Hisyam. \& Senarita Tarang Jenggie. (2012). The Impacts of Tourist's Expenditures on Malaysian Economy: An Input-Output Analysis. BIMP-EAGA Journal for Sustainable Tourism Development. 1 (1). 47 - 54.

Kweka, Josaphat. Oliver Morrissey. \& Adam Blake. (2003). The Economic Potential of Tourism in Tanzania. Journal of International Development. 15. 335 - 351.

Malba, Eldo. \&Taher, Iqbal M. (2016). Analisis Input-Output atas Dampak Sektor Pariwisata terhadap Perekonomian Maluku. Jurnal Bina Ekonomi. 20(2). hal 213-229.

Manhas, S P. Lalita A M. \&Ajay K M. (2016). Role of Tourist Destination Development in Building its brand image: A Conceptual Model. Journal of Economics, Finance and Administrative Science. 21. 25-29.

Munir, Qaiser. Mori Kogid. \&Mifli,Mazlan. (2015).Tourism and Economic Growth in Malaysia: Cointegration and Causality Analysis. Proceedings of the 7th International Conference of the Asian Academy of Applied Business (AAAB). China.

Shukla, Pawan Kumar. \& A A Ansari. (2013). Tourism and Resource Development: A Case Study of Gujarat.Periodic Research.2. 88 - 93.

Tantirigama, Tantri. \& Mei Taniguchi-Singh. (2009). Presented paper at NZAE conference. New Zealand.

Telce, Y.H. \& J.L. Schroenn.(2006). The Contribution of HRD to Tourism-Led Development in an African Context. South Africa Journal ofEconomics and Management Sciences. 4. 444457. 
Tugcu, C.T. (2014). Tourism and economic growth nexus revisited: A panel causality analysis for the case of the mediterranean region. Tourism Management. 42. 207-212.

United Nations. (2013). Sustainable Tourism: Contribution to economic growth and sustainable development. Expert Meeting on Tourism's Contribution to Sustainable Development.

Williams, Galina. (2016). Economic Impact from Development of the Coastal Town in Quensland on Tourism and Regional Economy. MDPI Journal. 5(4). 1 - 16.

Wuyts, Marc. \& Kilama, B. (2014). Economic Transformation in Tanzania: Vicious or Virtuous Circle?. ESRF Discussion Paper 56. 2.1-32.

Yousif, Mohammed Al. \& Ahmed Al Bakr. (2017). Tourism Development Effect On Saudi Economic Diversification. SAMA-Economic Research Department. 1-19.

Zhongmei, Guan. \&Juan,Wang. (2012). Study of the Tourism Development in Transformation of Resource-Based Cities - Take Jiaozuo City as an Example.IPEDR. 49 (28). $145-149$. 
